\title{
Pelatihan Penulisan Penelitian Tindakan Kelas Untuk Guru Sekolah Dasar
}

\author{
Yalvema Miaz ${ }^{1}$, Zuardi $^{2}$, Rafi Pebrian Putra ${ }^{3}$ \\ ${ }^{1,2,3}$ Pendidikan Guru Sekolah Dasar, Fakultas Ilmu Pendidikan, Universitas Negeri Padang \\ yalvema_miaz@fip.unp.ac.id
}

\begin{abstract}
ABSTRAK
Pengabdian ini dilatarbelakangi oleh rendahnya keterampilan guru sekolah dasar dalam menulis penelitian tindakan kelas. Tujuan penelitian ini adalah untuk melatih guru mengembangkan keterampilan guru dalam menulis penelitian tindakan kelas. Metode pengabdian ini menggunakan metode seminar dan pelatihan. Hasil pengabdian ini adalah guru mampu menulis penelitian tindakan kelas sesuai dengan baik. Implikasi pengabdian ini adalah sebagai acuan oleh praktisi pendidikan untuk meningkatkan keterampilan guru dalam menulis penelitian tindakan kelas.
\end{abstract}

Kata kunci: penelitian tindakan kelas, guru sekolah dasar

\section{ABSTRACT}

This dedication is motivated by the low skills of elementary school teachers in writing classroom action research. The purpose of this study is to train teachers to develop teacher skills in writing classroom action research. This service method uses seminar and training methods. The result of this dedication is the teacher is able to write classroom action research accordingly. The implication of this dedication is as a reference by education practitioners to improve teacher skills in writing classroom action research.

Keywords: classroom action research, elementary school teacher.

\section{PENDAHULUAN}

Kegiatan pengembangan profesi guru adalah penerapan keterampilan guru untuk peningkatan mutu pembelajaran dengan menggerakkan seluruh komponen yang menjadi subsistem dalam suatu sistem mutu pendidikan (Ginting \& Haryati, 2012) . Subsistem utama dalam peningkatan mutu pendidikan adalah faktor tersedianya guru yang profesional dengan kualifikasi dan kompetensi yang mampu memenuhi tuntutan tugasnya selama proses belajar mengajar berlangsung (Irwandi, 2016).

Guru yang profesional adalah guru yang selalu meningkatkan kompetensinya secara berkesinambungan, selalu kreatif, inovatif, serta menganalisis kelebihan dan kekurangan terhadap apa yang telah dilakukan dalam proses belajar mengajar yaitu melalui kegiatan Penelitian Tindakan Kelas (PTK) (Hamdi, 2015).

Dengan melakukan PTK para guru memperoleh banyak keuntungan. PTK dapat menumbuh kembangkan budaya meneliti bagi tenaga kependidikan agar lebih proaktif serta meningkatkan kolaborasi antar tenaga pendidik dan tenaga kependidikan dalam memecahkan masalah pembelajaran (Mawardi, 2014). PTK dapat memperbaiki dan meningkatkan mutu proses pembelajaran, dapat memperoleh angka kredit untuk kenaikan pangkat, dan dapat digunakan untuk memenuhi komponenkomponen karya pengembangan profesi dalam sertifikasi guru (Sani, 2012). Dengan memahami dan mencoba melaksanakan PTK, diharapkan kemampuan pendidik dalam proses pembelajaran makin meningkat kualitasnya dan sekaligus meningkatkan kualitas pendidikan serta profesi pendidik/tenaga kependidikan yang sekarang dirasakan menjadi hambatan. Selain memperbaiki kualitas pendidikan, PTK juga dapat dijadikan sebagai inovasi pembelajaran, pengembangan kurikulum, pengembangan profesi guru dan peningkatan mutu PBM (Sanjaya, 2016). Oleh sebab itu guru harus melaksanakan PTK untuk mencapai tujuan yang baik dalam proses pembelajaran termasuk pada guru SD

Permasalahan yang cukup dilematik dialami guru adalah hasil karya tulis ilmiah yang dibuat belum sesuai harapan tim penilai, sehingga banyak para guru yang tertahan kenaikan pangkatnya di golongan IVA, karena untuk naik ke IVB para guru harus memenuhi 
unsur pengembangan profesi menyusun karya tulis ilmiah dalam bentuk PTK (Pramswari, 2016) . Hal ini selaras dengan hasil wawancara dan penyebaran angket yang pengabdi lakukan.

Berdasarkan wawancara pengabdi dengan kepala sekolah SD Inti di Kota Padang Panjang ditemukan bahwa guru banyak yang tidak melanjutkan kenaikan pangkat ke IV b dikarenakan guru tidak melaporkan PTK yang dilakukan. Hal Ini diperkuat oleh hasil angket yan peneliti sebarkan disimpulkan bahwa guru tidak membuat laporan PTK diakibatkan lemahnya pengetahuan dan keterampilan guru dalam menulis laporan PTK.

Melihat tujuan PTK sangat penting bagi keprofesian guru serta adanya permasalahan yang terjadi mengenai lemahnya pegetahuan dan keterampilan guru dalam menulis PTK maka tujuan pengabdian ini adalah memberikan pelatihan kepada guru SD untuk mengembangkan pengetahuan dan keterampilan guru dalam menulis PTK.

\section{METODE KEGIATAN}

Peserta pengabdian ini adalah guru SDN 02 dan SDN 08 Kampung Manggis sebanyak 28 orang. Pelatihan ini dipusatkan di SDN 02 Kampung Manggis. Metode pelaksanaanya yaitu dengan menggunakan metode seminar dan pelatihan. Adapun penjelasanya sebagai berikut:

\section{Seminar mengenai Penelitian Tindakan Kelas}

Pada PKM ini diberikan seminar kepada guru SD. Seminar ini bertujuan untuk memberikan informasi kepada guru SD mengenai hakikat Penelitian Tindakan Kelas. Pada kegiatan ini gurudibekali informasi mengenai penelitian tindakan kelas berupa konsep dasar penelitian tindakan kelas dan prosedur penelitian tindakan kelas.

Luaran kegiatan ini adalah meningkatnya pengetahuan guru mengenai penelitian tindakan kelas dan menghasilkan referensi mengenai penelitian tindakan kelas.

2. Pelatihan Pengembangan dan Pelaksanaan Penelitian Tindakan Kelas Pada tahap ini guru dilatih untuk mengembangkan dan melaksanakan PTK. Pada kegiatan ini guru dibekali cara untuk menemukan masalah, menyusun latar belakang, merumuskan masalah, mengembangkan kajian teori, mengembangkan instrumen penelitian, dan penyusunan hasil dan pembahasan PTK.

Luaran kegiatan ini adalah meningkatnya keterampilan guru dalam mengembangkan dan melaksanakan PTK di sekolah dasar dan dihasilkanya laporan PTK di sekolah dasar.

Untuk mengukur keberhasilan PKM ini maka dilakukan evaluasi berupa penilaian pemahaman konsep dan penilaian keterampilan. Pengabdian dikatakan berhasil jika guru memiliki peningkatan dalam pemahaman konsep serta mendapatkan skor rata diatas 75 dan mendapatkan skor diatas 75 untuk setiap rata-rata indikator PTK.

\section{HASIL \& PEMBAHASAN}

Pembahasan akan dibagi menjadi dua bagian utama yaitu pembahasan seminar dan pelatihan. Adapun penjelasanya sebagai berikut:

\section{Seminar mengenail penelitian tindakan kelas}

Proses dilaksanakan dengan memberikan pengetahuan kepada guru mengenai konsep dasar penelitian tindakan kelas dan prosedur penelitian tindakan kelas. Kegiatan ini bertujuan untuk meningkatkan pengetahuan guru mengenai penelitian tindakan kelas dan menghasilkan referensi mengenail penelitian tindakan kelas Untuk mengakhiri guru diberikan evaluasi yang dijawab secara bersamaan pada ahir kegiatan.

Pemateri pada seminar ini adalah Rafhi Febriyan Putra. Beliau menyampaikan kepada peserta bahwa PTK digagasi oleh filosof yang bernawa Jhon dewey pada tahun 1990. Hal ini dilatar belakangi oleh pendekatan ilmiah yang adapa pada zaman dahulu tidak mampu menjadi sebuan inquiri dalam proses sosial sehingga permasalahan ini menimbulkan pandangan baru bahwa adanya kebutuhan terhadap permasalahan praktek yang tidak hanya sekedar permasalah teori. Permasalahan inilah yang terjadi didalam kelas sehingga perlunya penelitian yang dapat menjawab permasalahan sosial didalam kelas. Beliau menyampaikan

PTK merupakan suatu aktivitas penelitian yang dilaksanakan oleh guru didalam prosespembelajaran dikelas terhadap permaslaahan yang didapat dari hasil perenungan dan kegiatan ini diiringi dengan adanya tindakan/perlakukan yang bertujua untuk meningkatkan kualitas pembelajaran. PTK tidak hanya berbicara atau membahas siswa saja namun PTK juga membahas guru, 
siswa, kepala sekolah, hasil belajar, suasanan lingkungan dan pengelolaan kelas.

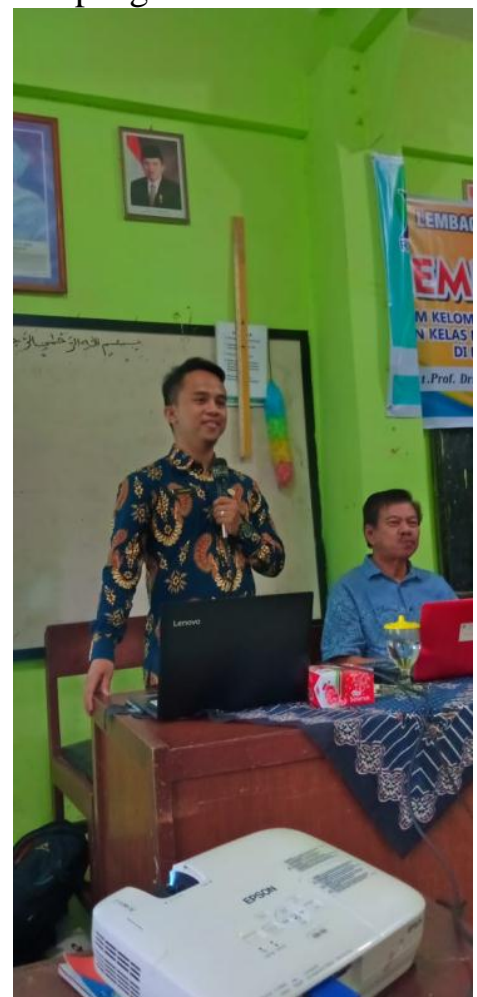

Gambar 1. pemateri memberikan materi

Beliau juga menyatakan bahwa PTK memiliki banyak tujuan dan mafaat. Selain untuk menyelesaikan permasalahan yang didalam kelas melalui tindakan yang dipilih, PTK juga bermanfaat untuk:
a. Menjadi panduan dalam meningkatkan kualitas pembelajaran.
b. Meningkatkan prodesionalisem guru dengan cara membiasakan diri untuk melakukan kegiatan menulis dan meneliti.
c. Sebagai alat pemecahan masalah bersama dengan cara kolaborasi guru baik didalam sekolah maupun antar sekolah.
d. Menambah wawasan guru dengan memahami permasalahan yang bertujuan untuk memperkuat dan meyeimbangkan pembelajaran dengan kebutuhan siswa.
e. Menambah motivasi siswa belajar melalui variasi tindakan yang dilakukan oleh guru.
f. Sebagai inovasi dalam pembelajaran.

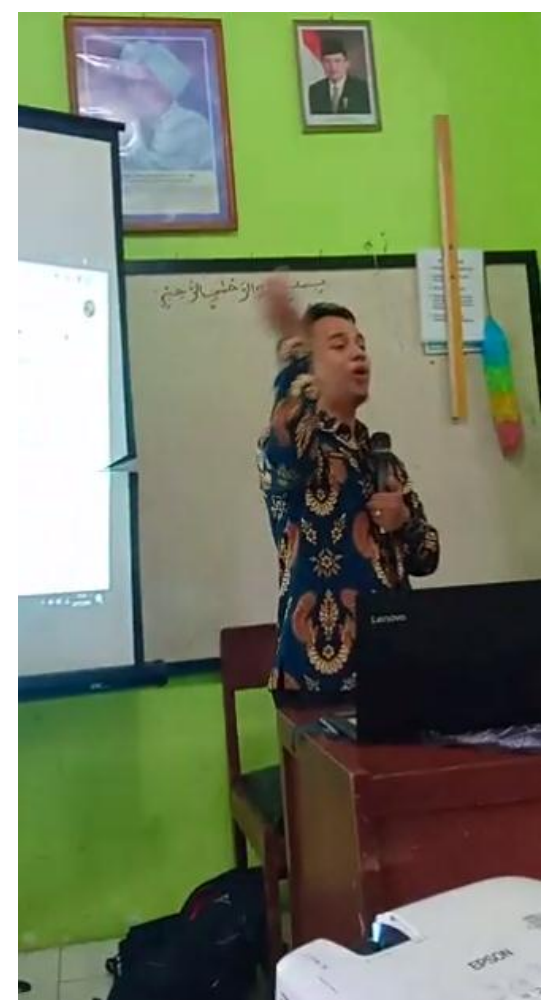

Gambar 2. pemateri memberikan Materi

Pada kesempatan ini pemateri juga mengemukakan bahwa PTK memiliki karakteristik sebagai berikut:

a. PTK tidak sekedar memecahkan maslaah namun menemukan faktafakta yang mendukung temuan tersebut.

b. PTK adalah saran untuk mengembangaknkan kemampuan berpikir kritis melalui kegiatan menulis dan meneliti.

c. Permasalahan berasal dari temuan didalam kelas bukan berasal dari analisis teori.

d. Pemraslaahan PTK bersifat sederhana, nyata, jelas dan tajam

e. PTK merupakan penelitian kolaborasi antara peneliti dan praktisi

f. PTK dapat dilaksanakan jika adanya komitmen bersama antara praktisi dan peneliti yang bertujuan untuk meningkatkan profesioanlisme guru dan memecahkan maslaah yang terjadi didalam kelas.

Selain itu, terdapat beberpa prinsip PTK yaitu:

a. Pengamatan maupun tindakan dalam penelitian tidak menganggu aktivitas pembelajarn utama siswa.

b. Masalah yang dipilih merupakan maslaah yang memiliki dampak 
yang besar dalam proses pembelajaran.

c. Pengumpulan data harus relatif singkat

d. Penyusunan penelitian harus dengan menggunakan metodologi penelitian yang tepat

e. Tetap menjaga etika dan sikap ilmiah selama penelitian

f. Kegiatan PTK merupakan kegiatan yang bersifat berkelanjutan

g. PTK tidak hanya sebatas ruangan kelas namun sepanjang yang berhubungan dengan visi-misi sekolah.

Pada seminar tersebut pemateri menyampaikan bahwa PTK tidak hanya sekedar menemukan permasalahan dalam proses pembelajaran tetapi bagaimana upaya guru untuk menemukan solusi dari masalahmaslaah yang ditemukan tersebut. Bapak rafhi menyampaikan bahwa PTK melibatkan secara aktif peran siswa dan guru dalam tindakan yang diberikan pada penelitian. Didalam PTK ada kegiatan refleksi/ renungan, kegiatan ini harus direnungkan secara rasional menggunakan teori agar tindakan perbaikan yang diberikan dapat memberikan dampak yang diinginkan. Beliau menyatakan bahwa dalam PTK terdapat siklus yang harus ditempuh. Siklus tersebut terdiri dari perencanaan, pelaksanaan, pengamatan dan refleksi.

Setelah itu beliau mengakhiri pertemuan. Diakhir pertemuan guru diberikan evaluasi.

\section{Pelatihan Pengembangan dan} Pelaksanaan Penelitian Tindakan Kelas.

Pada tahap ini guru dilatih untuk mengembangkan dan melaksanakan PTK. Adapun kegiatannya adalah: Pengenalan sistematika PTK, pelatihan teknik menemukan masalah, pelatihan teknik menyusun latar belakang, pelatihan teknik merumuskan masalah, pelatihan teknik mengembangkan masalah, pelatihan teknik menyusun latar belakang, pelatihan teknik mengembangkan kajian teori, pelatihan teknik mengembangan instrumen penelitian dan pelatihan teknik penyusunan hasil dan pembahasan.

Pemateri pada pelatihan ini adalah bapak Prof. Yalvema Miaz, M.Pd. Awal penyampaian pemateri menyatakan bahwa format PTK berbeda-beda tergantung dengan gaya selingkungan intansi yang meminta. Adapun komponen utamanya adalah judu, pendahuluan ( latar belakang, rumusan maslaah, tujuan penelitian dan manfaat hasil penelitian), kajian teori, metodologi penelitian, hasil dan pembahasan serta kesimpulan dasan saran.

Pemateri menyampaikan bahwa judul harus bersifat pada dan akurat terhadap permasalahan dan haru terdapat tindakan yang dilakukan untuk mengatasinya. Judul harus singkat, jelas dan sederhana yang ketika pembaca membaca mengetahui bahwa penelitian ini merupakan PTK. Usahakan judul PTK terdiri dari 20 Kata.

Setelah judul, pemateri membahas mengenai latar belakang masalah. Beliau menyampaikan bahwa dalam later belakang harus ada pembelajaran ideal (berdasarkan teori), kondisi yang terjadi dilapangan berdasarakan pengamatan, kajian teoritik yang mendukung tindakan yang dipilih, hasil penelitian yang relevan dan alasan perlunya diadakan penelitian ini.

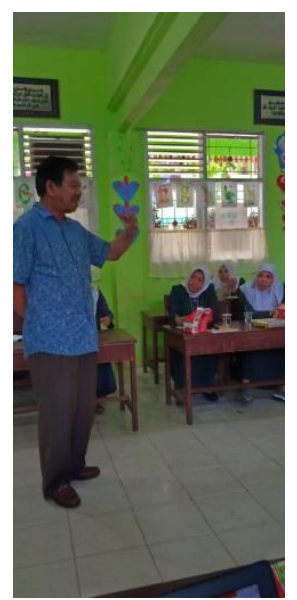

Gambar 3. Pemateri memberikan pelatihan

Selanjutnya pemateri menjelaskan mengenai rumusan masalah, tujuan penelitian dan manfaat hasil penelitian. Rumusan masalah harus terlihat kesenjangan antara kenayatan dengan kondisi yang diharapkan sedangakan tujuan penelitian harus bersifat kianti (Dapat diukur) dan tegas agar tujuan dpat dicapai. Beliau menyatakan bahwa manfaat hasil penelitian harus dapat berguna bagi guru, siswa dan intansi. 


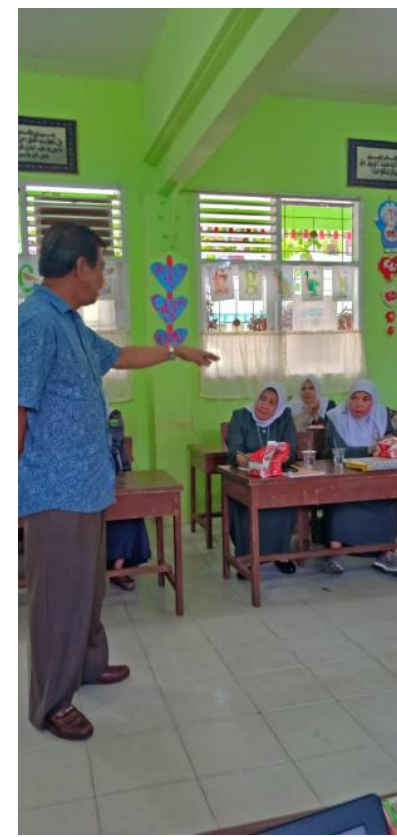

Gambar 4. Pemateril memberikan pelatihan

Pemateri menyampaikan dalam penulisan kajian teori harus sesuai dengan judul yang dipilih. Pengembangan kajian teori dikembangkan melalui kajian teori para ahli, dapat berupa buku, jurnal atau sumber lainya yang dapat dipercaya keabsahaannya. Pemateri menyampaikan untuk metodologi penelitian terdapat setting penelitian dan subyek penelitian. Selain itu ada perencanaan tindakan (terdiri dari skenarin pembelajaran yang dilaksanakan, persiapan alat dan media serta hal-hal lain yang dibutuhkan), pelaksanaan tindakan ( terdiri dari deksripsi tindakan yang dilaksanakan), evalusi, metode yang digunakan, instrumen, analisis data (terdiri dari prosedr analisis yang tepat dengan topik).

Pemateri menyatakan dalam menyusun hasil dan pembahasan disesuiakan dengan temuan yang didapati dalam proses peneliatian. Temuan ini disajikan kedalam tahapan perencanaan, pelaksanaan, pengamatan dan refleksi. Pembahasan difokusk kepada proses pemecahan masalah yang dikaitkan dengan kajian teoritik lainya yang mendukung hasil temuan.

Selama pelatihan berlangsung guru diajarkan secara langsung mengenai kiat-kiat menulis PTK jika ada pertanyaan guru langsung bertanya sehingga pertanyaan tersebut dijawab oleh prof Yal.

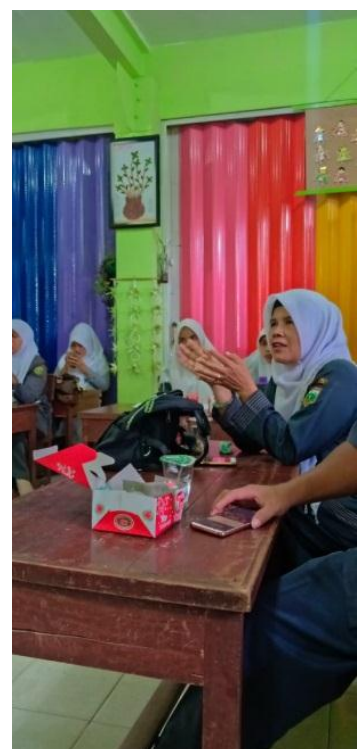

Gambar 5. guru sedang bertanya

Setelahnya pemateri mengakhiri pelatihan. Sebelum menutup acara, tim PKM memberikan evaluasi kepada guru untuk mengukur pemahaman guru mengenai pelatihan yang diberikan. Stelah itu tim meminta guru untuk membuat PTK dan kemudian dinilai

Setelah pengabdian berakhir maka pengabdi melakukan analisis keberhasilan kegiatan. Untuk melakukan analisis maka perlu penyajian data hasil penilaian pemahaman konsep dan penilaian keterampilan. Hasil penilaian rata-rata pemahaman konsep guru dapat dilihat pada grafik dibawah ini:

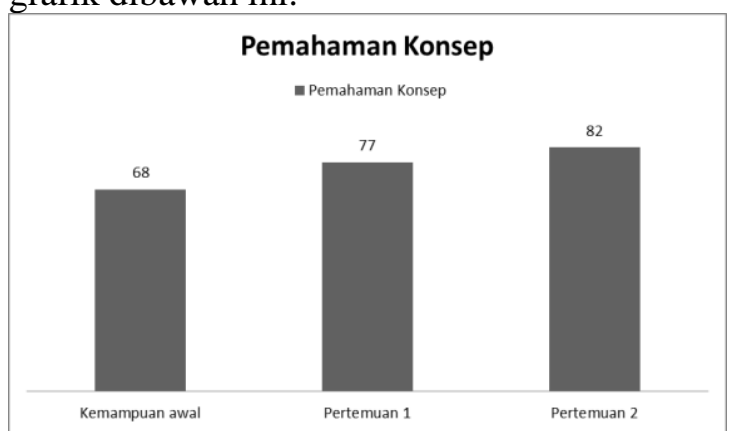

Garfik 1 Rata-rata hasil pemahaman konsep guru sekolah dasar

Berdasarkan grafik tersebut terlihat bahwa guru mengalami peningkatakan pengetahuan dan rata-rata kemampuan guru diatas 75. Selanjutnya rata-rata kemampuan keterampilan guru menulis PTK dapat dilihat pada grafik dibawah ini: 


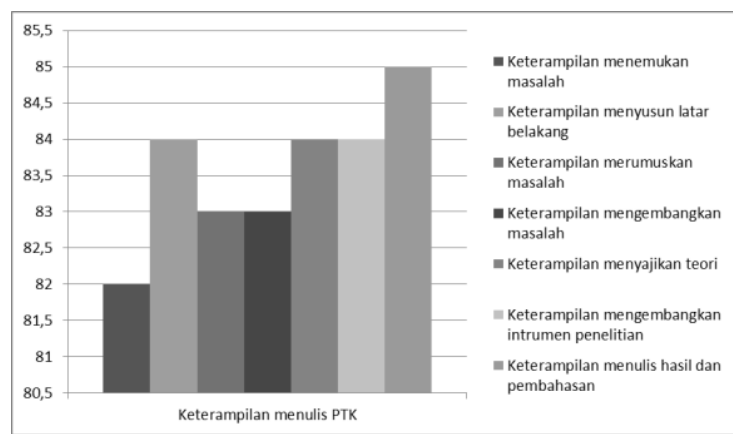

Grafik 2 Hasil kemampuan menulis PTK Guru SD

Berdasarkan grafik diatas terlihat bahwa guru memiliki kemampuan menulis PTK per indikator diatas 75. Berdasarkan data yang didapatkan mengenai pemahaman konsep dan keterampilan guru dalam menulis PTK dapat disimpulkan bahwa terjadinya peningkatan pemahaman guru dan keterampilan guru dalam menulis PTK. Hal ini membuktikan bahwa pengabdian ini berhasil karena indikator yang telah ditetapkan telah memenuhi target.

Penulisan PTK merupakan keharusan bagi guru sebagai pengembangan keprofesian. Tujuan utama PTK adalah untuk perbaikan dan meningkatkan pelayan profesi oleh pendidik dalam menangani proses belajar mengajar [9]. Tujuan itu dapat dicapai dengan melakukan dengan berbagai tindakan alternatif dalam memecahkan berbagai persoalan pembelajaran. Oleh karena itu fokus PTK terletak pada tindakan - tindakan alternatif yang direncanakan oleh pendidik, kemudian dicobakan dan selanjutnya dievaluasi apakah tindakan - tindakan alternatif itu dapat digunakan untuk memecahkan persoalan pembelajaran yang sedang dihadapi pendidik atau tidak. Oleh sebab itu guru harus mampu menulis PTK agar tercapainya tujuan tersebut.

Pengabdian ini membuktikan bahwa guru sekolah dasar telah mampu membuat PTK dengan baik. Hal ini disebabkan selama pengabdian berlangsung guru mengikuti kegaiatan dengan aktif sehingga tujuan pengabdian tercapai dengan baik. Keaktifan guru selama mengikuti pelatihan akan berpengaruh terhadap ketercapaian pelatihan (Rahmawati, 2014; Dewi \& Suhardini, 2014).

Keaktifan guru membuktikan bahwa guru memiliki motivasi yang tinggi untuk melaksanakan pelatihan. Motivasi tersebut berdampak terhadap ketercapaian tujuan pembelajaran (Hasanah, 2010; Fenia, 2018). Hal ini lah yang mempegaruhi keberhasilan dalam pengabdian ini.

\section{KESIMPULAN \& SARAN}

Pengabdian ini menyatakan terjadinya peningkatan pemahaman dan keterampilan guru SD terhadap kemampuan penulisan PTK serta dihasilkanya PTK oleh guru SD. Saran dari pengabdian ini adalah agar guru selalu melatih kemapuan menulis ini agar dapat meningkatkan keterampilanya.

\section{DAFTAR PUSTAKA}

Dewi, L., \& Suhardini, A. D. (2014). Peningkatan kompetensi pedagogik guru melalui pelatihan paikem (pelatihan pada guru MI dan MTS di Kabupaten Cianjur). Edutech, 13(1), 409-419.

Fenia, S. Z. (2018). Pengaruh Motivasi Kerja, Pelatihan Dosen Dan Komitmen Organisasi Terhadap Kinerja Dosen Pada Sekolah Tinggi X Di Sumatera Barat. Jurnal Benefita: Ekonomi Pembangunan, Manajemen Bisnis dan Akuntansi, 3(1), 76-83.

Ginting, R., \& Haryati, T. (2012). Kepemimpinan dan konteks peningkatan mutu pendidikan. CIVIS, 2(2), 1-10.

Hamdi, A. S., \& Bahruddin, E. (2015). Metode penelitian kuantitatif aplikasi dalam pendidikan. Jogjakarta: Deepublish.

Hasanah, D. S., Fattah, N., \& Prihatin, E. (2010). Pengaruh pendidikan Latihan (DIKLAT) Kepemimpinan Guru Dan Iklim Kerja terhadap Kinerja Guru Sekolah Dasar se Kecamatan Babakancikao Kabupaten Purwakarta. Jurnal Penelitian Pendidikan, 11(2), 8596.

Irwandi, I. (2016). Profesionalisme Dan Sertifikasi Guru Di Era Reformasi Pendidikan. Pionir: Jurnal Pendidikan, 5(2), 1-10.

Mawardi, M. (2014). Pemberlakuan Kurikulum SD/MI Tahun 2013 dan Implikasinya Terhadap Upaya Memperbaiki Proses Pembelajaran Melalui PTK. Scholaria: Jurnal Pendidikan dan Kebudayaan, 4(3), 107121.

Pramswari, L. P. (2016). Persepsi Guru SD Terhadap Penelitian Tindakan Kelas. Mimbar Sekolah Dasar, 3(1), 53-68.

Rahmawati, S. (2015). Pengaruh Pelatihan, Pengalaman Mengajar dan Kompensasi Terhadap Profesionalisme Guru di SMK Negeri 3 Palu. Katalogis, 3(12), 67-75

Sani, R. A. (2012). Meningkatkan profesionalisme guru Melalui Penelitian 
Tindakan Kelas. Medan: Citapustaka Media Perintis.

Sanjaya, D. H. W. (2016). Penelitian tindakan kelas. Jakarta: Prenada Media. 